\title{
The Utilization of Catfish Bone Waste as Microcalcium by Different Preparation Methods
}

\author{
Susana Endah Ratnawati ${ }^{*}$, Nurfitri Ekantari and Ustadi \\ Fisheries Department, Faculty of Agriculture, Gadjah Mada University, Indonesia
}

\begin{abstract}
In order to improve the quality of catfish bone flour, the sol-gel method was used to extract calcium. The purpose of the research was to compare calcium characterization, specifically chemical and physical quality based on discrepancy extraction methods. Completely Random Design was used as a factor with different calcium extraction, which were sol-gel method with agitation, a sol-gel treatment without agitation and the conventional way. Each treatment replicated in three folds. The results showed that the sol-gel process with agitation increased catfish bone flour quality $(\mathrm{p}<0.05)$, namely calcium $(16.02 \%)$ and phosphor (5.13). Compared to the conventional method, the sol-gel way with and without agitation reduced particle size from from micro to sub-micro size by $174.67 \mu \mathrm{m}$ to 3.82 and $5.12 \mu \mathrm{m}$ respectively. The highest whiteness index (84.18) made micro calcium prepared by sol-gel method with agitation process as prospective for food fortification. Based on microscopic observation, catfish bone flour has calcite shape and stable structure which prospective used to substitute calcium loss in the bone.
\end{abstract}

\section{Introduction}

Catfish production average in Yogyakarta is 52,025 ton, with the total production in Indonesia was $1,125,526$ ton in 2017 [1]. About 23.43 to $37.3 \%$ catfish body is bone, while the rests are muscle and viscera. Generally, catfish was sold in fresh or processed by frying, smoking, or fillet. It is suggested that the more catfish treated, the more bone waste produced. Therefore it is estimated that more than 12,000-ton bone was produced in Yogyakarta. Catfish bone preparation as calcium source can be applied as an alternative business for small enterprises in Yogyakarta.

Several studies related to calcium sources [2-4] used raw material mussel shells, fish scales, and gastropod shells respectively. Sol-gel method using $\mathrm{HCl}$ and $\mathrm{NaOH}$ produced calcium from catfish bone by $19.87 \%$ [5]. It is recorded that Ca-extraction can be done by hydrolysis using $5 \% \mathrm{NaOH}$ or $11.64 \% \mathrm{HCl}$ [6].

Tuna bone powder has calcium bioavailability by $0.86 \%$ [7], while that of in hake bone powder was about $2.47 \%$ [8]. Low calcium bioavailability need to be improved to maximize its application in food $[9,10]$. The small size particle in food material can

\footnotetext{
* Corresponding author: susana.endah@ugm.ac.id
} 
optimize food absorption [11]. It is noted that the bioavailability of nanocalcium were $63.3 \%$ and $75.1 \%$ respectively $[12,13]$.

Particle size, which is small and homogenous, can be done by modification between solgel and agitation method. Calcium flour can be homogenized by $15,000 \mathrm{rpm}$ agitation during four minutes [10], while another research used the stirring method by 3,000 rpm for five minutes to extract nano size calcium [4]. Agitation can be modified by $1,300 \mathrm{rpm}$ during one hour to homogenized calcium size [14]. This research is conducted to analyze the effectivity of the agitation process in calcium flour preparation and to know the chemical and physical characteristics caused by the different extraction process. Agitation was adjusted and compared with traditional method, particularly by chemical and physical assesments.

\section{Materials and methods}

Catfish bone was supplied by small manufacturers in Sleman, Yogyakarta. Chloride acid $(\mathrm{HCl})$, sodium hydroxide $(\mathrm{NaOH})$, aquadest were obtained from Sigma. Bone and head were washed to remove attached material, packed in the styrofoam box and stored in -20 ${ }^{\circ} \mathrm{C}$.

Calcium flour was prepared in three different methods, namely conventional method, sol-gel method with agitation and sol-gel method without agitation. The conventional method was started with boiling (bone water ratio 1:2 w/v) for 15 minutes. Subsequently, bone was separated from muscles and fat then washed with aquadest. Later on, bone was processed with an autoclave for 60 minutes to soften the bone and dried using the oven at $60{ }^{\circ} \mathrm{C}$ for 24 hours. Finally, it was ground and sieved into a smaller particle. Sol-gel method [4] were started by washing the bone; then it was continued with mineral extraction using $8 \% \mathrm{HCl}$ at $70{ }^{\circ} \mathrm{C}$ for 5 hours. Subsequently, the suspension was precipitated using $1 \%$ $\mathrm{NaOH}$. The precipitation process will be done by agitation $(700 \mathrm{rpm}$ during 3 hours and without agitation process). The precipitate was rinsed using aquadest until neutral then dried at $650{ }^{\circ} \mathrm{C}$ (Fig. 1).

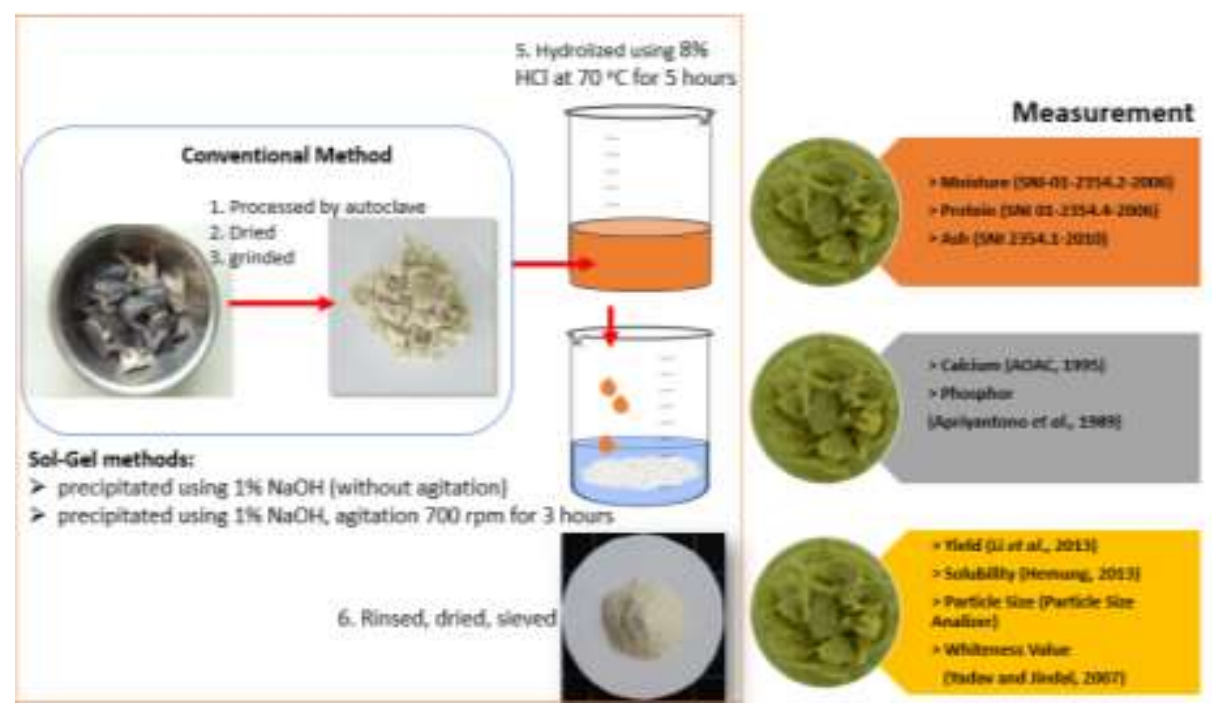

Fig 1. Schematic description of microcalcium preparation. 


\subsection{Yield}

Yield value was measured based on the weight percentage of the sample per raw material (w/w) [15].

\subsection{Moisture content}

Moisture content was done by following SNI-01-2354.2-2006 methods [16]. About 2 grams sample was vacuum dried at $95-105^{\circ} \mathrm{C}$ for 5 hours and continued with drying at $105^{\circ} \mathrm{C}$ during 16-24 hours. Later on, it was placed on desiccator for 30 minutes before measured the moisture content.

\subsection{Protein content}

Protein content was done with the Kjeldahl method (SNI 01-2354.4-2006) [17]. The sample was added with $\mathrm{K}_{2} \mathrm{SO}_{4}, \mathrm{HgO}, \mathrm{H}_{2} \mathrm{SO}_{4}$, and $3 \mathrm{ml} \mathrm{H}_{2} \mathrm{O}_{2}$. Subsequently, the sample was aged in the acid solution for 10 minutes and continued with the destruction process at $410^{\circ} \mathrm{C}$. After it reached ambient temperature, the sample was added with aquadest and $\mathrm{NaOH}-\mathrm{NaS}_{2} \mathrm{O}_{3}$ solution. The destilation process was done with $\mathrm{H}_{3} \mathrm{BO}_{3} 4 \%$ before measure the protein content.

\subsection{Ash content (SNI 2354.1-2010)}

Ash content was analyzed using the furnace (SNI 2354.1-2010). About $2 \mathrm{~g}$ sample was placed into a porcelain chamber then heated at $100{ }^{\circ} \mathrm{C}$ for $16-24$ hours. Subsequently, it was burned in the furnace [18].

\subsection{Calcium content (AOAC, 1995)}

Calcium content was performed by Atomic Absorption Spectrophotometer (AAS) in 420 $\mathrm{nm}$ wave. The sample was initially destructed in wet condition [19].

\subsection{Phosphor content (Apriyantono et al., 1989)}

About $5 \mathrm{~g}$ sample was added with nitrate acid, sulfuric acid, and aquadest. Subsequently, it was heated then dissolved. The solution was measured by spectrophotometer at $400 \mathrm{~nm}$ wave [20].

\subsection{Particle size and morphology}

Particle size was measured by Particle Size Analyzer while morphology was investigated by using SEM microscope.

\subsection{Whiteness Index value (WI)}

Whiteness value was measured by using whiteness meter. The analysis was done by whiteness index (WI) with the range scale 0 (black colour) to 100 (white colour) [21].

\subsection{Solubility}

Fishbone powder was mixed with aquadest and stirred at room temperature overnight, then filtered through filter paper. The retentate was dried before weighing to obtain the insoluble particle [10]. 


\subsection{Statistical Analysis}

This research was Completely Randomized Design (CRD) with the factor is a different method of micro calcium preparation. Data were analyzed using ANOVA and Tukey HSD test to know the differences among the treatments by Minitab 14 version.

\section{Results and discussion}

\subsection{Chemical characteristic}

Table 1. illustrates that catfish bone powder prepared by the sol-gel method in both stirring or without stirring modification showed a higher amount of ash (98.25-98.40\%) and Ca content (14.02-16.02\%). Conventionally, the number of $\mathrm{Ca}$ content was only a quarter (4.78\%) compared to that of prepared by sol-gel methods. The higher amount of ash content extracted by the sol-gel process, the more calcium content can be measured.

The organic phase inside the bone is calcium phosphate or hydroxyapatite $\mathrm{Ca}_{10}(\mathrm{PO} 4)_{6}(\mathrm{OH})_{2}$, which are deposited among the collagen matrix [22]. On the other hand, phosphor showed different percentages regardless of the discrepancy methods. The wide range of chemical forms of phosphor in nature resulted in difficulties to standardize in its storage because of the potential degradation and the rate of transformation are highly variable [23]. One of the factors which influence calcium absorption is the $\mathrm{Ca} / \mathrm{P}$ ratio. The best ratio was provided by catfish bone flour prepared by sol-gel methods with an agitation, which was $3 / 1(\mathrm{Ca} / \mathrm{P})$. Calcium absorption will be more effective if $\mathrm{Ca} / \mathrm{P}$ ratio is balanced $(1 / 1$ to $3 / 1 \mathrm{Ca} / \mathrm{P})[24,25]$.

The small amount of protein $(0.00-0.05 \%)$ and moisture $(0.57-0.58 \%)$ contents were determined in such methods. The average of cod, blue whiting, salmon, herring, mackerel protein content is $26-41 \%$ [26]. It is suggested that the deproteinized process can effectively separate mineral from material residues such as pigment, protein, blood, and fat. Generally, protein deposited in the bone formed as stroma, namely collagen. It is defined that stroma is easier dissolved in both acid or base solvent. Stroma will be cut into peptide molecules which are easy to separate $[15,6]$. The drying process is perfectly performed. In contrast, the conventional method left about $6.14 \%$ moisture content, which resulted in the agglomeration of the powder during storage.

Table 1. Chemical characteristics of catfish bone microcalcium

\begin{tabular}{|l|c|c|c|}
\hline \multicolumn{1}{|c|}{ Parameter } & With agitation & Without agitation & conventional \\
\hline Ash content $(\%)$ & $98.25^{\mathrm{a}} \pm 1.57$ & $98.40^{\mathrm{ac}} \pm 1.52$ & $70.48^{\mathrm{bd}} \pm 1.37$ \\
\hline Protein $(\%)$ & $0.00^{\mathrm{a}} \pm 0.001$ & $0.05^{\mathrm{a}} \pm 0.02$ & $18.55^{\mathrm{bc}} \pm 1.44$ \\
\hline Moisture content $(\%)$ & $0.57^{\mathrm{a}} \pm 0.02$ & $0.58^{\mathrm{ac}} \pm 0.13$ & $6.14^{\mathrm{bd}} \pm 0.07$ \\
\hline $\mathrm{Ca}(\%)$ & $16.02^{\mathrm{a}} \pm 0.71$ & $14.02^{\mathrm{ac}} \pm 1.36$ & $4.78^{\mathrm{bd}} \pm 0.15$ \\
\hline $\mathrm{P}(\%)$ & $5.13^{\mathrm{a}} \pm 1.03$ & $14.32^{\mathrm{b}} \pm 2.13$ & $13.39^{\mathrm{bc}} \pm 3.62$ \\
\hline $\mathrm{Ca} / \mathrm{P}$ ratio & $3 / 1$ & $1 / 1$ & $1 / 2.8$ \\
\hline
\end{tabular}

\subsection{Physical characteristics}

The result of physical measurement of microcalcium was presented in Table 2 . Microcalcium showed yield by 11.19 to $51.78 \%$. Even though sol-gel preparation with stirring modification provided the small amount of yield of $11.19 \%$; mineral and calcium sources produced was far higher compared to the other methods. Therefore, it can be seen that the majority component in powder was mineral. Moreover, the smallest particle size which reached to sub-micron size $(3.82 \mu \mathrm{m})$ resulted in the higher solubility (Fig. 2). The low solubility can be solved by an acid-based food application, for instance, juice, milk of bread. 


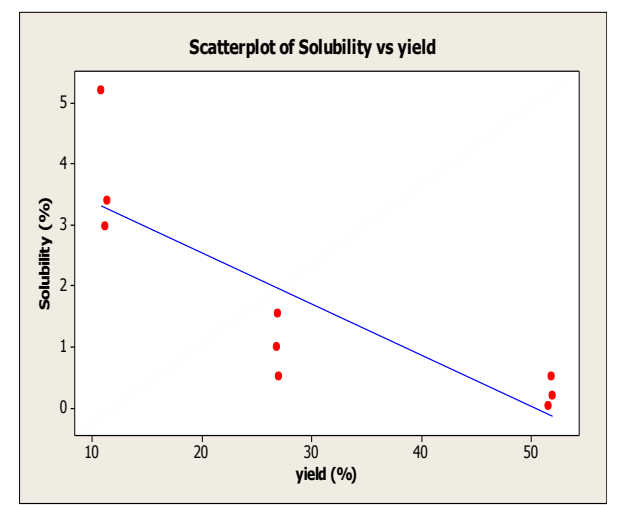

(a)

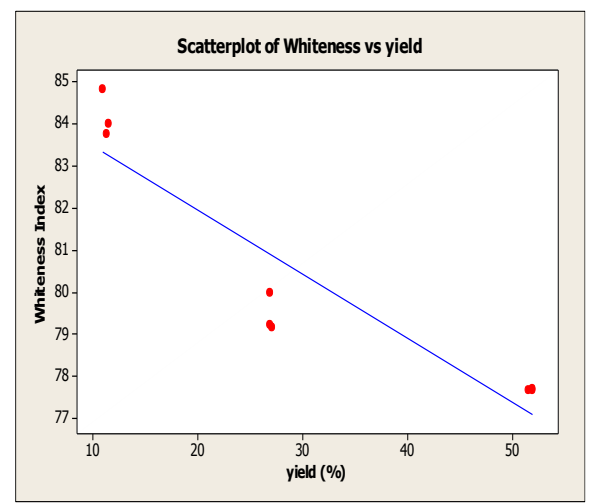

(b)

Fig 2. Correlation between solubility and yield (a) and Whiteness Index and yield (b)

It is recorded that nanocalcium fortified in milk has absorbtion level to $90 \%$, while it took only two third $(65 \%)$ by microcalcium [27]. Nanocalcium can be absorbed to receptor faster than microcalcium [13]. The results were not showed nanosize particle. It is suggested that during the precipitation process supernatant showed aggregation because of the high of particle density and solvent interaction. It also revealed a porous and small aglomerate crystal. The interaction of surface area and solution was continously stirred for three hours to prevent the bigger aglomeration. The particle size can be reached by improving solvent concentration or surfactant addition. Sodium tripolyphosphate decreases the particle size from 1-2 $\mu \mathrm{m}$ to $100-200 \mathrm{~nm}$ [28].

Table 2. The effect of different treatments on physical characteristics

\begin{tabular}{|l|l|l|l|}
\hline \multicolumn{1}{|c|}{ Physical characteristics } & \multicolumn{1}{|c|}{ With agitation } & \multicolumn{1}{|c|}{ Without agitation } & \multicolumn{1}{c|}{ Conventional } \\
\hline Yield & $11.19^{\mathrm{a}} \pm 0.27$ & $26.90^{\mathrm{bd}} \pm 0.10$ & $51.78^{\mathrm{ce}} \pm 0.19$ \\
\hline Solubility & $3.86^{\mathrm{a}} \pm 1.18$ & $1.02^{\mathrm{bd}} \pm 0.52$ & $0.24^{\mathrm{cd}} \pm 0.24$ \\
\hline PSA & $3.82^{\mathrm{a}} \pm 0.06$ & $5.12^{\mathrm{ac}} \pm 0.47$ & $174.67^{\mathrm{bd}} \pm 5.86$ \\
\hline
\end{tabular}

The size and structural surface analysis of micro calcium using SEM micrograph showed calcite formation (Fig. 3). Calcium crystal consists of three different configurations namely calcite (cube form), aragonite (pin form) and vaterite (flower-like) [29]. Generally, shell powder has aragonite shape, however the addition of alcaline solution (e.g. $\mathrm{NaOH}$, $\mathrm{NaClO}, \mathrm{KOH}$, and $\mathrm{LiOH}$ ) enable transform the aragonite to calcite shape which implies mineralization process in sub-micron particle size [30]. In addition, the calcite form is generally found in nature and more stable at ambient temperature and atmosphere [28]. 


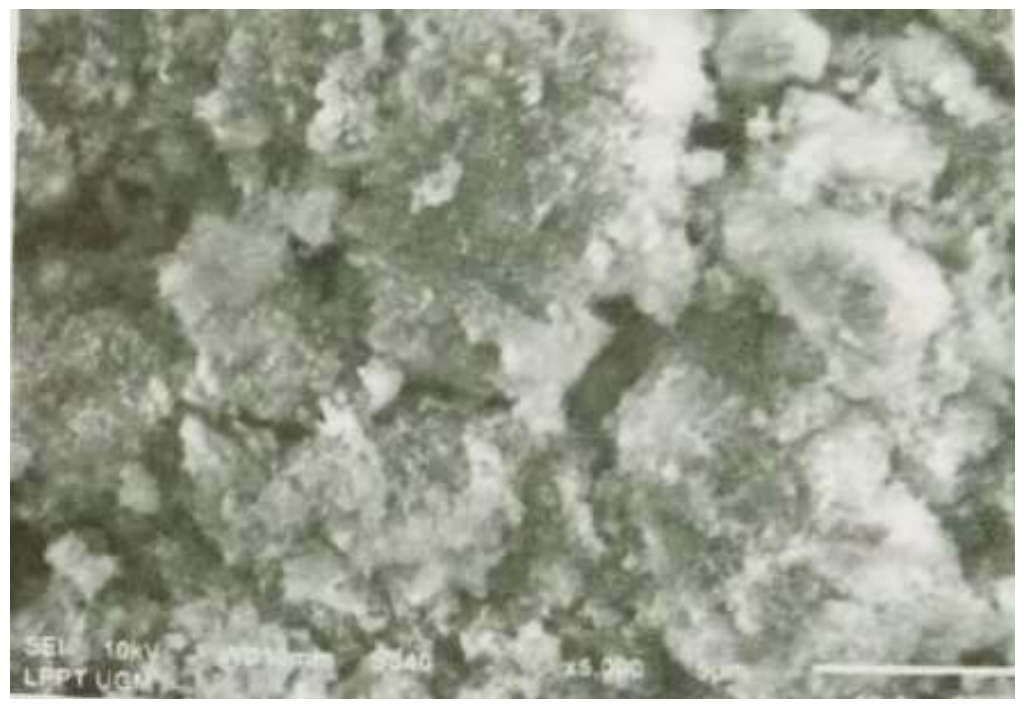

Fig 3. Scanning Electron Microscopy (SEM) Image of microcalcium

The colour of micro calcium was shown visible as a different white powder and the whiteness indexes, as shown in Table 3. The intensity is correlated with the organic residues. The high content of organic compound resulted in the less delicate of micro calcium. The deproteinizing caused white colour revealed by micro calcium (WI 84.18) prepared by the sol-gel method with stirring modification during precipitation. Precipitation takes a role in crystal formation and dissolving fat and protein residual. Yellowish white colour (WI 79.45) which revealed in micro calcium produced by the conventional method is related to protein and fat content while heating in a high temperature $\left(650{ }^{\circ} \mathrm{C}\right)$ resulted in Grayish white colour (WI 77.67). Related to food fortification white powder is preferable for consumers; in contrast, organic compounds give less delicate colour [10].

Table 3. The effect of different methods on colour of the fishbone powder

\begin{tabular}{|l|c|c|c|c|}
\hline \multicolumn{1}{|c|}{ Sample } & L & a & b & $\begin{array}{c}\text { Whiteness Index } \\
(\text { WI })\end{array}$ \\
\hline With agitation & $84.18 \pm 0.38$ & $2.52 \pm 0.18$ & $7.67 \pm 1.13$ & $84.18^{\text {a }} \pm 0.56$ \\
\hline Without agitation & $79.45 \pm 0.47$ & $2.04 \pm 0.07$ & $7.70 \pm 1.10$ & $79.45^{\text {b }} \pm 0.47$ \\
\hline Conventional & $71.80 \pm 0.11$ & $1.55 \pm 0.04$ & $17.15 \pm 0.20$ & $77.67^{\text {cd }} \pm 0.02$ \\
\hline
\end{tabular}

The majority of micro calcium flour provided powder textures wheat flour-like [31]. The conventional way revealed a coarse agglomeration powder as the higher moisture content $(6.14 \%)$. The lower the moisture content, the more stable calcium powder during storage. Microbial growth can be inhibited by diminishing moisture content to $2 \%$ [10].

Texture provided by sol-gel methods gave more delicate powder because of hydrolysis process using a high concentration of $\mathrm{HCl}$ during 2 hours followed by precipitation process. It is illustrated that the combination of solvent concentration and time of immersion resulted in bone matrix swelling so that the solvent can be more accessible to extract mineral content [13].

Microcalcium processed by the sol-gel method provided neutral odour. To prepared calcium flour, fishbone needs to be separated from the amino acid, protein, enzyme, collagen, and volatile compound [32]. SNI No. 3751-2009 defined that one of the quality standards of flour is a neutral odour [31] (Fig.4). 
Table 4. The effect of treatments on microcalcium-physical characteristics

\begin{tabular}{|l|l|l|l|l|}
\hline \multicolumn{1}{|c|}{ Sample } & \multicolumn{1}{|c|}{ Texture } & \multicolumn{1}{c|}{ Odour } & \multicolumn{1}{c|}{ Colour } & \multicolumn{1}{c|}{ Appearance } \\
\hline Conventional method & Coarse powder & Fishy smell & $\begin{array}{l}\text { Yellowish } \\
\text { white }\end{array}$ & $\begin{array}{l}\text { Tiny } \\
\text { agglomeration }\end{array}$ \\
\hline $\begin{array}{l}\text { Sol-gel method agitation 700 } \\
\text { rpm, 3 hours }\end{array}$ & Refined powder & Neutral & White & Powder-like \\
\hline $\begin{array}{l}\text { Sol-gel method without } \\
\text { agitation }\end{array}$ & Refined powder & Neutral & Grayish white & Powder-like \\
\hline
\end{tabular}

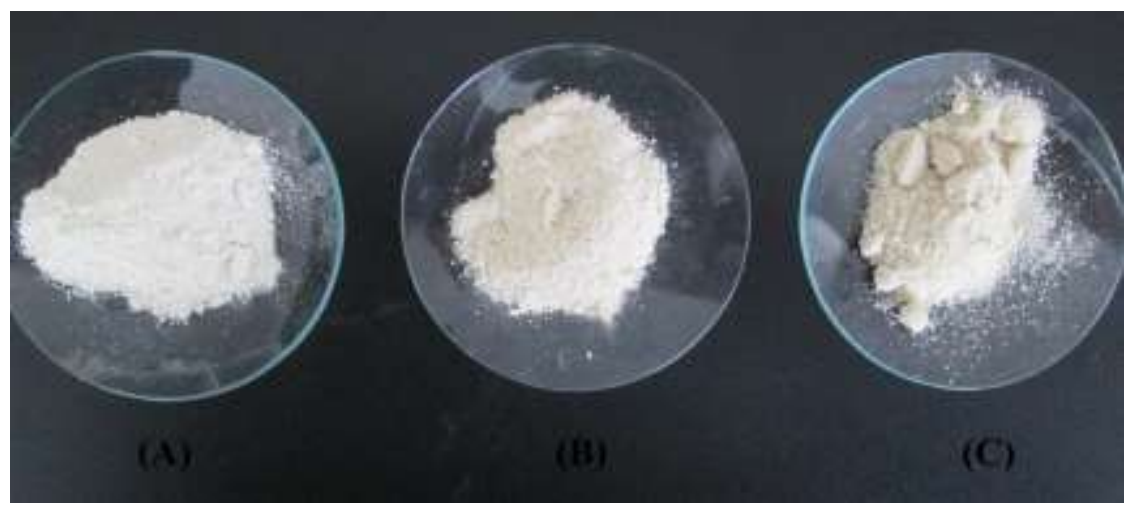

Fig 4. Microcalcium Produced by Different Methods

\section{Conclusion}

Different methods of calcium preparation resulted in a variety of characteristics. It is clearly understood that the sol-gel way with agitation process by $700 \mathrm{rpm}$ during 3 hours was successfully reduced phospor content, increase solubility and whiteness index. It enables to extract of ash, calcium, and phosphor effectively. In addition sol gel method with both agitation or without agitation The solubility of micro calcium was found at a low percentage yet it was still prospective be applied in acid based food.

\section{Acknowledgment}

Gadjah Mada University which provides funding. My gratitude for Brigitta Laksmi and Sari Dwi Hastuti.

\section{References}

1. Pusat Data, Statistik, dan Informasi. 2018. Satuan Data Produksi Kelautan dan Perikanan Tahun 2017 (Pusat Data, Statistik, dan Informasi Kementerian Kelautan dan Perikanan, 2018)

2. Kongsri, Supalak, K. Janpradit, K. Buapa, S.Techawongstien, S. Chanthai, Chemical Engineering Journal 215-216, 522-532 (2013) 
3. Shavandi, A., A.D.A. Bekhit, A. Ali, Z. Sun, Materials Chemistry and Physics 149150, 607-616 (2015).

4. Oladoja, N. A., I.A. Ololade, S.E. Olaseni, V.O. Olatujoye, O.S.Jegede and A.O. Agunloye, Industrial and Engineering Chemistry Research 51, 639-648 (2011)

5. Ratnawati, Susana Endah, N. Ekantari, R. W. Pradipta. Physycochemical Characterization of Calcium Flour Made from Catfish Bone Waste (Research Report Faculty of Agrivulture UGM, 2015)

6. Rey, C., C. Combes, C. Drouet, M.J. Glimcher, Osteoporos Int 20, 1013-1021 (2009)

7. Thai, C.Y., and C. Chen, Chemical Engineering Science 63, 3632-3642 (2008)

8. Martinez, Isabel., M. Santaella, G. Ros, M. J. Periago, Food Chemistry 63 (3), 299305 (1998)

9. Trilaksani, Wini, Ella S., and N, Muhammad, Buletin Teknologi Hasil Perikanan 9(2), 34-45 (2006).

10. Hemung, Bung Orn, International Journal of Bioscience, Biochemistry and Bioinformatics 3 (4), 306-309 (2013).

11. Chaudhry, Qasim, L. Castle, R. Watkins. 2010. Nanotechnologies In food. The Royal Society of Chemistry. 245 pages.

12. Minarty. I. S. The Application of Nanocalcium from Crab Shell (Portunus sp.) on Efervescent. (Departemen Hasil Perairan. Fakultas Perikanan dan Kelautan. Institut Teknologi Bogor, 2012)

13. Suptijah, P., Jacoeb, A., Deviyanti, N, Jurnal Akuatika 3(1), 63 - 73 (2012).

14. Mijan, N.A., Y.H. Taufiq-Yap, H.V. Lee, Chemical Engineering Journal 262, 1043 1051 (2015).

15. Li, Yun-Fang., Wu, Yu., Espinosa, Nayelli Hernandez., Pena, Roberto J, Journal of Cereal Science 57, 398 - 404 (2013)

16. Standar Nasional Indonesia. Chemical Test Chapter 2: Moisture Determination on Seafood Products (SNI 01-2354.2-2006) (Badan Standarisasi Nasional, 2012)

17. Standar Nasional Indonesia, Chemical Test Chapter 4: Protein Determination using Total Nitrogen Method on Seafood Products (SNI 01-2354.4-2006). (Badan Standarisasi Nasional, 2006)

18. Standar Nasional Indonesia Chemical Test Chapter 1: Ash and unsoluble ash Determination on Seafood Products (SNI 01-2354.1-2006) (Badan Standarisasi Nasional, 2006)

19. Association of Official Analytical and Chemists [AOAC]. Official Methods of Analysis the 16th ed. (Virginia: Inc. Arlington, 1995)

20. Apriyantono A, Fardiaz D, Puspitasari NL, Sedarwati, Budiyanto S, Analisis Pangan.(Pusat Antar Universitas Pangan dan Gizi IPB, 1989)

21. Yadav, B.K. \& Jindal, V. K, Journal of Food Engineering 86, 113-121 (2007)

22. Purwasasmita, B.S., R.S. Gultom, Jurnal Bionatura 10(2), 155-167 (2008)

23. Jarvie, H.P., J.A. Withers, C. Neil. Hydrology and Earth System Science 6 (1), $113-$ 132 (2002).

24. Agustini, Tri Winarni, S. E. Ratnawati, B. A. Wibowo, J. Hutabarat, Jurnal Pengolahan Hasil Perikanan Indonesia 14 (2), 134-142 (2011)

25. Ratnawati, S.E., T.W. Agustini, J. Hutabarat, Jurnal Perikanan 2, 88-103 (2014)

26. J. Toppe, S. Albrektsen, B. Hope, and A. Aksnes. Comparative Biochemical and Physiology 146, 395-401 (2007)

27. Erfanian, Arezoo., H. Mirhosseini, M. Y.A. Manap, B. Rasti, M. H. Bejo, Food Research International. 66, 1-11 (2014)

28. Thai, C.Y., and C. Chen. Chemical Engineering Science 63, 3632-3642 (2008)

29. Saksono N, Mubarok MH, Widaningroem R, Bismo S. Jurnal Teknologi 4, 317-323 (2007) 
30. Lu, J., Z. Lu, X. Li, H. Xu., X. Li. Journal of Cleaner Production 92, 223-229 (2015)

31. Standar Nasional Indonesia. Wheat Flour as Food Material SNI No. 3751-2009 (Badan Standar Nasional Indonesia, 2009)

32. Piccirilo, C., M.F. Silva, R.C. Pullar, I. B. Da Cruz, R. Jorge, M.M.E. Pintado, P.M.L. Castro. Material Science and Engineering 33, 103-110 (2013) 